Meta

Journal des traducteurs

Translators' Journal

\title{
Bibliographie des livres canadiens en traduction : 1580-1974
}

\section{Maureen Newman et Philip Stratford}

Volume 20, numéro 1, mars 1975

Vingt ans de traduction. Bilan et prospectives

URI : https://id.erudit.org/iderudit/004308ar

DOI : https://doi.org/10.7202/004308ar

Aller au sommaire du numéro

Éditeur(s)

Les Presses de l'Université de Montréal

ISSN

0026-0452 (imprimé)

1492-1421 (numérique)

Découvrir la revue

Citer ce document

Newman, M. \& Stratford, P. (1975). Bibliographie des livres canadiens en traduction : 1580-1974. Meta, 20(1), 83-105. https://doi.org/10.7202/004308ar d'utilisation que vous pouvez consulter en ligne.

https://apropos.erudit.org/fr/usagers/politique-dutilisation/ 


\section{Bibliographie des livres canadiens en traduction: $1580-1974$}

En 1968 Meta publia une modeste bibliographie de traductions d'œuvres littéraires canadiennes ${ }^{1}$ qui contenait 68 titres. Cette publication était néanmoins la seule de son espèce à l'époque et servit d'amorce à d'autres recherches pour aboutir à la présente liste qui comporte 250 titres de livres traduits du français en anglais et 120 titres de livres traduits de l'anglais en français. Malgré le fait que cette bibliographie est de loin la plus complète qui existe actuellement dans ce domaine, ses auteurs n'ont pas la prétention d'avoir épuisé la matière et seraient heureux d'accepter les titres additionnels ou les corrections que l'on voudra bien leur transmettre.

La bibliographie est divisée en deux parties :

A. Traductions du français en anglais ;

B. Traductions de l'anglais en français.

Pour faciliter la consultation, les deux parties sont subdivisées en catégories selon les genres suivants : 1) roman, 2) poésie, 3) théâtre, 4) folklore, 5) lettres, rapports, relations de voyage, 6) essais, 7) anthologies, 8) bibliographies.

Les auteurs espèrent avoir fourni un bon outil de travail à l'usage des traducteurs, libraires, chercheurs, professeurs, éditeurs et agences gouvernementales. Ils sont reconnaissants de cette occasion de voir paraitre leurs travaux dans les pages de Meta, et ils remercient également le Conseil canadien de recherches sur les humanités de leur avoir accordé les subventions nécessaires pour accomplir cette tâche. Le C.C.R.H. a également accepté de faire paraître sous forme de brochure la présente bibliographie augmentée d'une liste de 67 projets de traductions en cours, ainsi que les index des auteurs et traducteurs des ouvres citées.

Il pourrait sembler aux yeux des non-initiés que pour un pays bilingue le Canada ait accompli assez peu de chose dans le domaine de la traduction. Ceci est. exact jusqu'à un certain point, mais en toute justice on se doit de souligner que ne sont pas incluses dans le présent ouvrage les publications faites sous l'égide du gouvernement. L'organisme Information Canada a précisé que pendant les 200 dernières années plus de 100000 documents ont été traduits par les services provinciaux et fédéraux.

1. Philip Stratford, «French-Canadian Literature in translation ", Meta, XIII (décembre 1968), 180-187. 
Le domaine de la présente bibliographie est limité aux œuvres qui appartiennent à la littérature, aux arts et aux sciences humaines ainsi qu'au travail de traducteurs individuels et non d'agences anonymes; il semble en l'occurrence plus important de mettre en relief une courbe de croissance plutôt qu'une masse brute.

À partir de très modestes débuts, quand les textes traduits étaient principalement des récits d'explorateurs ne paraissant qu'au rythme d'une demi-douzaine par siècle, nous avons progressivement atteint une moyenne annuelle d'une quarantaine de traductions. De 1920 à 1960 il y a eu plus d'ouvrages traduits que pendant les 350 années précédentes ; pendant la décennie 1960-1970, le nombre des traductions a presque triplé et depuis les derniers cinq ans il y a eu autant de traductions publiées que durant la période 1960-1970. Cette expansion rapide est due sans aucun doute à l'initiative prise par le Conseil des arts du Canada au début des années 60 pour favoriser la traduction. Depuis 1972 particulièrement, des subventions accordées par le Secrétariat d'État ont encouragé l'élan des éditeurs canadiens dans ce domaine.

Si l'on analyse ces listes d'un peu près on y découvre cependant certaines anomalies. Dans la catégorie du roman, par exemple, on remarquera que près de $70 \%$ des traductions françaises des romans canadiens-anglais ont été publiées en France et non au Québec et que la moitié des titres appartient à l'œuvre de trois romanciers : Arthur Hailey, Malcolm Lowry et Mazo de la Roche. De semblables phénomènes apparaissent également du côté anglais où un tiers des traductions de romans canadiens-français a été publié en Grande-Bretagne ou aux États-Unis et un tiers du nombre total de romans traduits est l'œuvre de quatre auteurs : MarieClaire Blais, Gabrielle Roy, Louis Hémon et Roch Carrier. Les traductions anglaises non seulement ont paru depuis plus longtemps et en plus grand nombre (un peu plus du double) que les traductions françaises, mais elles semblent être plus éclectiques. Les traductions françaises n'ont commencé à paraître de façon appréciable qu'après 1960 et là encore ne comportaient presque exclusivement que des œuvres classées dans les catégories «essais» et "romans». Malgré un meilleur équilibre du côté anglais on remarque pourtant que ces même catégories comprennent $70 \%$ des œuvres traduites. Le théâtre et la poésie, par exemple, malgré leur richesse dans la culture québécoise, viennent tout juste de faire leur apparition en traduction. On doit signaler un autre fait, bien qu'il ne soit pas inclus dans la présente bibliographie : c'est qu'au moins une centaine d'ouvrages parmi les 370 titres cités et peut-être même jusqu'à la moitié du total sont actuellement épuisés.

Si comme le dit Naïm Kattan « la traduction ouvre la porte d'une civilisation à une autre ${ }^{2}$ », on pourrait conclure que les relations entre les deux cultures du Canada ont été plutôt hivernales et témoignent d'un voisinage aussi indifférent qu'inhospitalier. Pourtant il y a eu des changements appréciables depuis les dix dernières années : plus de traductions ont été publiées durant cette période que pendant la somme des années précédentes; grâce à l'appui du Conseil des arts la publication des traductions a été en large mesure rapatriée et une variété bien plus étendue qu'auparavant en ce qui concerne les auteurs, les styles et les genres est

2. Naim Kattan, * Translation ", Scholarly Publishing, October 1974, p. 31. 
maintenant offerte au public canadien. D'autre part, comme il existe de plus en plus d'œuvres disponibles en traduction, elle paraissent de plus en plus fréquemment dans des anthologies. Faisant retour en arrière, il arrive que bien des classiques retrouvent une nouvelle jeunesse grâce à la traduction et les lacunes qui existaient dans nos connaissances de l'autre partie de notre héritage culturel sont en train d'être comblées. Il est aussi permis d'espérer que dans l'avenir il y aura moins de décalage entre la parution d'un livre et la publication de sa version traduite et même que les œuvres importantes paraîtront simultanément dans les deux langues. Par le passé quelques distingués hommes de lettres, canadiens tels que Sir Charles G. D. Roberts, B. K. Sandwell, Pamphile Lemay, Marius Barbeau, Alain Grandbois, s'essayèrent parfois à la traduction. Cette tendance se poursuit, particulièrement en poésie avec les travaux d'Anne Hébert et de Frank Scott ; à cet égard on devrait également signaler le travail accompli par la revue trimestrielle Ellipse qui est principalement consacrée aux traductions poétiques. Il est très intéressant de noter qu'un groupe d'écrivains est apparu récemment, Alan Brown, Sheila Fischman, John Glassco, Joyce Marshall, Jean Paré et Jean Simard pour n'en citer que quelques-uns, qui par la qualité de leur œuvre et la variété de leurs entreprises se sont mérité le titre de traducteurs de haut talent portant cet art à un niveau proche de la création littéraire. Il est permis de conclure que grâce à leurs efforts la porte commence véritablement à s'ouvrir entre nos deux cultures.

Maureen Newman et Philip Stratford

\section{A. TRANSLATIONS FROM FRENCH TO ENGLISH *}

\section{(A. 1) FICTION}

Aquin, Hubert. Prochain épisode. Montréal: Cercle du Livre de France, 1965. Trans. Penny Williams. Prochain épisode. Toronto: McClelland \& Stewart, 1967, rpt. Toronto : NCL, 1973.

L'Antiphonaire. Montréal : Cercle du Livre de France, 1969. Trans. Alan Brown. The Antiphonary. Toronto : Anansi, 1973.

Aubert de Gaspé, Philippe-Joseph. Les Anciens Canadiens. Québec : Desbarats \& Derbishire, 1863. Trans. Georgiana M. Penée. The Canadians of Old. Quebec: Desbarats, 1864 ; rpt. with changes as Seigneur d'Haberville: A Romance of the Fall of New France. Toronto : Musson, 1929.

Trans. Charles G. D. Roberts. The Canadians of Old. New York: Appleton, 1890 ; rpt. as Cameron of Lochiel. Toronto : Copp Clark, 1905 ; also rpt. as Canadians of Old. Toronto : McClelland \& Stewart, NCL, 1974.

Aubry, Claude. Les îles du roi Maha Maha II. Montréal : Éditions du Pélican, 1960. Trans. Alice Kane. The King of the Thousand Islands: a Canadian Fairy Tale. Toronto : McClelland \& Stewart, 1963.

Le Loup de Noël. Montréal : Centre de Psychologie et de Pédagogie, 1962. Trans. Alice Kane. The Christian Wolf. Toronto: McClelland \& Stewart, 1965.

Beaugrand, Honoré. La Chasse-galerie : légendes canadiennes. Montréal : n. pub., 1900. Trans. Honoré Beaugrand. La Chasse-galerie and other Canadian Stories. Montréal : Pelletier, 1900.

\footnotetext{
* Copyright CCRH
} 
Bessette, Gérard. Le Libraire. Paris : Julliard, 1960. Trans. Glen Shortlife. Not for Every Eye. Toronto : Macmillan, 1962.

L'Incubation. Montréal : Librairie Déom, 1965. Trans. Glen Shortliffe. Incubation. Toronto : Macmillan, 1967.

Blais, Marie-Claire. La Belle bête. Québec: Institut Littéraire du Québec, 1959. Trans. Merloyd Lawrence. Mad Shadows. Toronto : McClelland \& Stewart, 1960; rpt. NCL, 1971.

—. Tête Blanche. Québec : Institut Littéraire du Québec, 1960. Trans. Charles Fullman. Tête Blanche. Toronto : McClelland \& Stewart, 1961 ; rpt. NCL, 1974.

Le Jour est noir. Montréal : Les Éditions du Jour, 1962.

Les Voyageurs sacrés. Montréal: Éditions HMH, 1969. Trans. Derek Coltman. The Day Is Dark and Three Travellers. New York: Farrar, Straus \& Giroux, 1967. (Includes both the above)

Une Saison dans la vie d'Emmanuel. Montréal: Les Éditions du Jour, 1965. Trans. Derek Coltman. A Season in the Life of Emmanuel. New York : Farrar, Straus \& Giroux, 1966.

David Sterne. Montréal : Éditions du Jour, 1967. Trans. David Lobdell. David Sterne. Toronto : McClelland \& Stewart, 1973.

Manuscrits de Pauline Archange. Montréal : Éditions du Jour, 1968.

Vivre! Vivre!: la suite des manuscrits de Pauline Archange. Montréal : Éditions du Jour, 1969. Trans. Derek Coltman. Both of the above are included in The Manuscripts of Pauline Archange. New York : Farrar, Straus \& Giroux, 1970.

Le Loup. Montréal : Éditions du Jour, 1972. Trans. Sheila Fischman. The Wolf. Toronto : McClelland \& Stewart, 1974.

Carrier, Roch. La Guerre, yes sir ! Montréal : Éditions du Jour, 1968. Trans. Sheila Fishman. La Guerre, Yes Sir! Toronto: Anansi, 1970.

Floralie, où est-tu? Montréal : Éditions du Jour, 1969. Trans. Sheila Fischman. Floralie, Where Are You? Toronto : Anansi, 1971.

Il est par là, le soleil. Montréal : Éditions du Jour, 1970. Trans. Sheila Fischman. Is It the Sun, Philibert? Toronto : Anansi, 1972.

. Le Deux-millième étage. Montréal : Éditions du Jour, 1973. Trans. Sheila Fischman. They Won't Demolish Me. Toronto : Anansi, 1974.

Conan, Laure (pseud. for Félicité Angers). À l'auvre et à l'épreuve. Québec: C. Darveau, 1891. Trans. Theresa A. Gethin. The Master Motive: A Tale of the Days of Champlain. St. Louis, Mo. : Herder, 1909.

Constantin-Weyer, Maurice. La Bourrasque. Paris : J. Ferenczi et fils, 1919. N. Trans. The Half-breed. New York: Macaulay, 1930. N. trans. A Martyr's Folly. Toronto : Macmillan, 1930.

- Vers l'ouest. Paris : La Renaissance du Livre, 1921. N. Trans. Towards the West. N.Y. : Macaulay, 1931.

Cavalier de La Salle. Paris : Rieder, 1927. N. trans. The French Adventurer: The Life and Exploits of LaSalle. New York : Macaulay, 1931.

Clairière. Paris : Mornay, 1929. Trans. Conrad Elphinstone. Forest Wild. London : G. Routledge, 1932.

Dantin, Louis (pseud. for Eugène Seers). Les Enfances de Fanny. Montréal : Chanteclerc, 1951. Trans. Ray Chamberlain. Fanny. Montréal : Harvest House, 1973.

Darios, Louise. Contes étranges du Canada. Montréal : Beauchemin, 1962. Trans. Philippa C. Gerry. Strange Tales of Canada. Toronto : Ryerson, 1965.

Doutremont, Henri (pseud. for Georges Bugnet). Nipsya. Montréal : Garand, 1924. Trans. Constance D. Woodrow. Nipsya. New York : Louis Carrier, 1929.

Ducharme, Réjean. L'Avalée des avalés. Paris : Gallimard, 1966. Trans. Barbara Bray. The Swallower Swallowed. London : Hamish Hamilton, 1968. 
Élie, Robert. La Fin des songes. Montréal : Éditions Fides, 1950. Trans. Irene Coffin. Farewell My Dreams. Toronto : Ryerson, 1954.

Ferron, Jacques. Cotnoir. Montréal: Éditions d'Orphée, 1962. Trans. Pierre Cloutier. Dr. Cotnoir. Montréal : Harvest House, 1973.

Contes, édition intégrale: Contes anglais, Contes du pays incertain, Contes inédits. Montréal : HMH, 1968. Trans. Betty Bednarski. Tales from the Uncertain Country. Toronto: Anansi, 1972. (Includes 18 of the 44 tales collected above)

France, Claire (pseud. for Claire Morin). Les Enfants qui s'aiment. Montréal : Beauchemin, 1956. Trans. Antonia White. Children in Love. Toronto : McClelland \& Stewart, 1959.

Fréchette, Louis-Honoré. A Selection. Trans. Maurice Francis Egan. Warner's Library of the World's Best Literature. N. Y. : Warner, 1917. Includes fragments from La Légende d'un Peuple, Caughnawaga, Les Feuilles volantes.

Giguère, Diane. Le Temps des jeux. Montréal : Cercle du Livre de France, 1961. Trans. Peter Green. Innocence. Toronto : McClelland \& Stewart, 1962.

L'Eau est profonde. Montréal : Le Cercle du Livre de France, 1965. Trans. Charles Fullman. Whirlpool. Toronto : McClelland \& Stewart, 1966.

Godbout, Jacques. Le Couteau sur la table. Paris : Éditions du Seuil, 1965. Trans. Penny Williams. Knife on the Table. Toronto : McClelland \& Stewart, 1968.

Salut Galarneau! Paris: Éditions du Seuil, 1967. Trans. Alan Brown. Hail Galarneau! Toronto : Longmans, 1970.

Guévremont, Germaine. Le Survenant. Montréal: Fides, 1945. Trans. Eric Sutton. The Outlander. Toronto : McGraw-Hill, 1950; also Monk's Reach. London : Evan Bros., 1950.

Harvey, Jean-Charles. Les Demi-civilisés. Montréal : Éditions du Totem, 1934. Trans. Lukin Barette. Sackcloth for Banner. Toronto : Macmillan, 1938.

Hẻbert, Anne. Le Torrent. Montréal : Beauchemin, 1950. Trans. Gwendolyn Moore. The Torrent. Montréal : Harvest House, 1973.

Kamouraska. Paris : Éditions du Seuil, 1970. Trans. Norman Shapiro. Kamouraska. Toronto: Musson, 1973.

Hébert, Jacques. Les Écceurants. Montréal : Éditions du Jour, 1966. Trans. Gérald Taafe. Temple on the River. Montréal : Harvest House, 1967.

Hémon, Louis. Maria Chapdelaine. Paris : Delagrave, 1916. Trans. W. H. Blake. Maria Chapdelaine: A Tale of the Lake St. John Country. N.Y.: Macmillan, 1921; also rpt. Toronto : Macmillan, 1973.

Trans. Andrew McPhail. Maria Chapdelaine. Montréal : Chapman, 1921.

La Belle que voilà. Paris : B. Grasset, 1923. Trans. William Aspenwall Bradley. My Fair Lady. N.Y. : Macmillan, 1923.

Colin-Maillard. Paris: B. Grasset, 1924. Trans. Arthur Richmond. Blind Man's Buff. New York : Macmillan, 1924.

- Battling Malone, pugiliste. Paris: B. Grasset, 1925. Trans. William Aspenwall Bradley. Battling Malone and Other Stories. London : T. Butterworth, 1925.

Monsieur Ripois et la Némésis. Paris, B. Grasset, 1950. Trans. William Aspenwall Bradley. Monsieur Ripois and Nemesis. New York : Macmillan, 1925.

Jasmin, Claude. Ethel et le terroriste. Montréal : Librairie Déom, 1964. Trans. David S. Walker. Ethel and the Terrorist. Montreal : Harvest House, 1965.

Langevin, André. Poussière sur la Ville. Montréal : Cercle du Livre de France, 1953. Trans. John Latrebe and Robert Gottlieb. Dust over the City. McClelland \& Stewart, 1955 ; rpt. Toronto : NCL, 1974.

Leclerc, Félix. Allegro. Montréal : Fides, 1944. Trans. Linda Hutcheon. Allegro. Toronto: McClelland \& Stewart, NCL, 1974. 
LeFranc, Marie. Grand Louis l'innocent. Montréal : La Patrie, 1925. Trans. George and Hilda Shively. The Whisper of a Name. Indianapolis : Bobbs-Merrill, 1928.

Lemelin, Roger. Au pied de la pente douce. Montréal: Éditions de l'Arbre, 1944. Trans. Samuel Putman. The Town Below. New York: Reynal \& Hitchcock, 1948 ; rpt. Toronto : McClelland \& Stewart, NCL, 1961.

Les Plouffes. Québec: Belisle, 1948. Trans. Mary Finch. The Plouffe Family. Toronto : McClelland \& Stewart, 1950.

Pierre le magnifique. Québec : Institut littéraire du Québec, 1952. Trans. Harry Lorne Binsse. In Quest of Splendour. Toronto: McClelland \& Stewart, 1955.

Marcotte, Gilles. Le Poids de diett. Paris: Flammarion, 1962. Trans. Elizabeth Abbott. The Burden of God. New York : Vanguard Press, 1964.

Marie-Victorin, Frère (Conrad Kirouac). Récits Laurentiens. Paris : Casterman, 1919. Trans. James Ferres. The Chopping Bee and Other Laurentian Stories. Toronto : Musson, 1925.

Mélançon, Claude. Légendes indiennes du Canada. Montréal : Éditions du Jour, 1967. Trans. David Ellis. Indian Legends of Canada. Agincourt, Ont. : Gage, 1974.

Nantel, Adolphe. À la hache. Montréal : A. Lévesque, 1932. Trans. B. K. Sandwell. A Saga of Lac Clair. Montréal : privately printed, 1937. (A selection)

Renaud, Jacques. Le Cassé. Montréal : Parti Pris, 1964. Trans. Gérald Robitaille. Flat Broke and Beat. Montréal : Bélier, 1964.

Ringuet (pseud. for Philippe Panneton). Trente arpents. Paris : Flammarion, 1938. Trans. Dorothea and Felix Walker. Thirty Acres. New York: Macmillan, 1940; rpt. Toronto : NCL, 1960.

Rivard, Adjutor. Chez Nous. Québec: L'Action Sociale Catholique, 1914. Trans. W. H. Blake. Chez Nous: Our Old Quebec Home. Toronto: McClelland \& Stewart, 1924.

Routhier, Adolphe-Basile. Le Centurion: roman des temps messianiques. Lille : Desclée, De Brouwer, 1909. Trans. Lucille P. Borden. The Centurion : a Romance of the Time of the Messiah. St. Louis, Mo. : Herder, 1910.

Roy, Gabrielle. Bonheur d'occasion. Paris : Flammarion, 1945. Trans. Hannah Josephson. The Tin Flute. New York : Reynal \& Hitchcock, 1947 ; rpt. Toronto : NCL, 1958.

La Petite poule d'eau. Montréal : Beauchemin, 1950. Trans. Harry Binsse. Where Nests the Water Hen. New York: Harcourt Brace, 1951; rpt. Toronto : NCL, 1961.

Alexandre Chênevert. Montréal: Bauchemin, 1954. Trans. Harry Lorne Binsse. The Cashier. New York: Harcourt, Brace, 1955; rpt. Toronto: NCL, 1963.

Rue Deschambault. Montréal : Beauchemin, 1955. Trans. Harry Binsse. Street of Riches. New York : Harcourt, Brace, 1957 ; rpt. Toronto : NCL, 1967.

La Montagne secrète. Montréal : Beauchemin, 1961. Trans. Harry Lorne Binsse. The Hidden Mountain. Toronto: McClelland \& Stewart, 1961; rpt. NCL 1974.

La Route d'Altamont. Montréal : Éditions HMH, 1966. Trans. Joyce Marshall. The Road Past Altamont. Toronto : McClelland \& Stewart, 1966.

. La Rivière sans repos. Montréal: Beauchemin, 1970. Trans. Joyce Marshall. Windflower. Toronto : McClelland \& Stewart, 1970.

Savard, Félix-Antoine. Menaud, maître-draveur. Montréal : Fides, 1937. Trans. Alan Sullivan. Boss of the River. Toronto : Ryerson, 1947.

Thériault, Yves. Agaguk. Québec : Institut littéraire du Québec, 1958. Trans. Miriam Chapin. Agaguk. Toronto : Ryerson, 1963.

Ashini. Montréal : Editions Fides, 1960. Trans. Gwendolyn Moore. Ashini. Montréal : Harvest House, 1972.

N'Tsuk. Montréal : Éditions de l'Homme, 1968. Trans. Gwendolyn Moore. N’Tsuk. Montréal : Harvest House, 1971. 
Vigneault, Gilles. Contes sur la pointe des pieds. Québec: Éditions de l'Arc, 1960. Trans. Paul Allard. Tales (Sur la Pointe des Pieds). Erin, Ont. : Porcépic, 1972.

\section{(A. 2) POETRY}

Chamberland, Paul. L'Afficheur hurle. Montréal : Parti Pris, 1964. Trans. Malcolm Reid. The Shouting Signpainters. Toronto: McClelland \& Stewart, 1972. (A selection)

Fréchette, Louis-Honoré. Les Excommuniés. The Excommunicated: Episode in the History History of Canada. Trans. G. W. Wickstead. N.p. n.d.

Garcia, Juan. L'Alchimie du corps. Montréal: Hexagone, 1967. Trans. Marc Plourde. L'Alchimie du Corps. Fredericton : Fiddiehead, 1974.

Garneau, Hector de Saint-Denys. Poésies complètes: Regards et jeux dans l'espace, Les Solitudes. Montréal : Fides, 1949. Trans. Jean Beaupré and Gael Turnbull. Nine Poems. Iroquois Falls, Ont. : Contact Press, 1955. (A selection of 9 poems)

Trans. Frank R. Scott. Saint-Denys Garneau and Anne Hébert: Translations/ traductions. Vancouver: Klanak, 1962. A selection of 9 poems in a bilingual edition)

Trans. John Glassco. The Complete Poems of Saint-Denys Garneau. Ottawa: Oberon, 1974.

- Journal. Montréal: Éditions Beauchemin, 1954. Trans. John Glassco. The Journal of Saint-Denys Garneau. Toronto : McClelland and Stewart, 1962.

Giguère, Roland. Les Armes blanches. Montréal : Éditions Erta, 1954. Trans. Jean Beaupré and Gael Turnbull. Eight Poems. Iroquois Falls, Ont. : Contact Press, 1955. (A selection of 8 poems)

Grandbois, Alain. Poèmes : Les îles de la nuit, Rivages de l'homme, L'Étoire pourpre. Montréal : Hexagone 1963.

"Aube ", "Le Vide ". Liberté 60. No. 8. March-April, 1960. Trans. Peter Miller. Selected Poems. Toronto : Contact Press, 1964.

Hébert, Anne. Les Songes en équilibre. Montréal : Éditions de l'Arbre, 1942.

Le Tombeau des rois. Québec : L'Institut Littéraire du Québec, 1953.

Poèmes. Paris: Éditions du Seuil, 1960. Trans. Frank R. Scott. Saint-Denys Garneau and Anne Hébert: Translations/traductions. Vancouver: Klanak, 1962. (A selection of 9 poems in a bilingual edition)

Le Tombeau des rois. Québec: L'Institut littéraire du Québec, 1953. Trans. Frank R. Scott. Saint-Denys Garneau and Anne Hébert: Translations/traductions. Vancouver : Klanak, 1962.

Trans. Peter Miller. The Tomb of the Kings. Toronto : Contact Press, 1967.

Trans. Anne Hébert and Frank Scott. Dialogue sur la traduction à propos du «Tombeau des rois $»$. Montréal : HMH, 1970.

Hénault, Gilles. Théâtre en plein air. Montréal : Les Cahiers de la File indienne, 1946.

Totems. Montréal : Erta, 1953. Trans. Jean Beaupré and Gael Turnbull. Seven Poems. Iroquois Falls, Ont.: Contact Press, 1955. (A selection of 7 poems)

Lapointe, Gatien. «Face à face. "Le Premier Mot, précédé de Le Pari de ne pas mourir. Montréal : Éditions du Jour, 1967. Trans. Fred Cogswell. Confrontation. Fredericton : Fiddlehead, 1973.

Lapointe, Paul-Marie. Le Vierge incendié. Montréal: Mithra-Mythe, 1948. Trans. Jean Beaupré and Gael Turnbull. Six Poems. Iroquois Falls, Ont.: 1955. (A selection of 6 poems)

Nelligan, Émile. Poésies complètes, 1896-1899. Montréal : Fides, 1952. Trans. P. F. Widdows. Selected Poems. Toronto : Ryerson, 1960. 


\section{(A. 3) DRAMA}

Barbeau, Jean. Le Chemin de Lacroix. Montréal : Leméac, 1971. Trans. Laurence R. Bérard and Philip W. London. The Way of Lacross. Toronto : Playwright's Co-op, 1972. Manon Lastcall et Joualez-moi d'amour. Montréal : Leméac, 1972. Trans. Philip W. London and Susan K. London. Manon Lastcall. Montréal : Centre d'Essai des Auteurs Dramatiques, 1973.

Dubé, Marcel. Au retour des oies blanches. Montréal : Leméac, 1969. Trans. Jean Remple. The White Geese. Toronto : New Press, 1972.

Dufresne, Guy. Le Cri de l'Engoulevent. Montréal : Leméac, 1969. Trans. Philip London and Laurence Bérard. The Call of the Whippoorwill. Toronto: New Press, 1972.

Gélinas, Gratien. Tit-Coq. Montréal: Beauchemin, 1950. Trans. Kenneth Johnson and Gratien Gélinas. Tit-Coq. Toronto : Clarke, Irwin, 1967.

Bousille et les justes. Montréal: Éditions de l'homme, 1960. Trans. Kenneth Johnson and Joffre Miville-Dechêne. Bousille and the Just. Toronto: Clarke, Irwin, 1961.

Hier les enfants dansaient. Montréal: Leméac, 1968. Trans. Mavor Moore. Yesterday the Children Were Dancing. Toronto: Clarke, Irwin, 1967.

Gurik, Robert. Le Procès de Jean-Baptiste M. Montréal : Leméac, 1972. Trans. Allan Van Meer. The Trial of Jean-Baptiste M. Vancouver : Talonbooks, 1974.

Le Pendu. Montréal : Leméac, 1970. Trans. Philip London and Laurence R. Bérard. The Hanged Man. Toronto : New Press, 1972.

Lescarbot, Marc. Le Théâtre de Neptune en la Nouvelle France. Représenté sur les flots du Port Royal le quatorzième de novembre mille six cens six. In his Histoire de la Nouvelle France. Paris, 1866. Trans. Harriet Taber Richardson. The Theatre of Neptune in New France, Presented upon the Wases of Port Royal the Fourteenth Day of November, Sixteen Hundred and Six, on the Return of the Sieur de Poutincourt from the Armouchiquois Country. Boston : Houghton Mifflin, 1927.

Prévost, Arthur. French and Langlais of Wakanda. Trans. Arthur Prévost. (A bilingual edition). Sorel, Québec : Les Éditions Princeps. n.d.

Tremblay, Michel. En pièces détachées et La Duchesse de Langeais. Montréal : Leméac, 1970 Trans. Allan Van Meer. Like Death Warmed Over. Toronto : Playwright's Coop, 1973. (A translation of En pièces détachées)

\section{(A. 4) FOLKLORE}

Aubry, Claude. Le Violon magique et autres légendes du Canada français. Ottawa : Éditions des Deux Rives, 1968. Trans. Alice Kane. The Magic Fiddler and Other Legends of French Canada. Toronto : Peter Martin Assoc., 1968.

Barbeau, Charles Marius. Chansons canadiennes. French-Canadian Folk Songs. Trans. Paul England. Arr. by Healey Willan. London : Frederick Harris Co., 1929.

Chansons Populaires du vieux Québec. Ottawa: Dept. of Northern Affairs \& National Resources, 1935. Trans. Regina Lenore Shoolman. Folk-songs of Old Quebec. Ottawa : Dept. of Northern Affairs \& National Resources, 1935.

L'Arbre des rêves. Montréal: Lumen, 1947. Trans. Charles Marius Barbeau. The Tree of Dreams. Toronto : Oxford Univ. Press, 1955.

Les Contes du grand-père sept heures. Montréal: Chantecler, 1950-53. 12 vols. Trans. Michael Hornyanski. The Golden Phoenix and Other French-Canadian Fairy Tales. London: Oxford Univ. Press, 1958. (Includes 8 of the above tales)

Fréchette, Louis-Honoré. La Noël au Canada. Toronto: G. N. Morang, 1900. Trans. C. G. D. Roberts. Christmas in French Canada. Toronto: G. N. Morang, 1899.

Montigny, Louvigny Testard de. Le Bouquet de Mélusine, scènes de folklore. Montréal : L. Carrier, 1928. Trans. J. Murray Gibbon. The Order of Good Cheer: Canadian Historical Ballad Opera of the First Settlers in Canada. Toronto: Dent, 1929. 


\section{(A. 5) LETTERS, REPORTS, TRAVEL JOURNALS}

Cartier, Jacques. Voyages. Trans. John Florido. A Shorte and Briefe Narration of the Two Nauigations and Discoueries to the Northweast Partes Called Newe Fravnce. London : H. Bynneman, 1580. (From the Italian trans. by Gio. Bapt. Ramutius.)

Champlain, Samuel de. Les Voyages de la Nouuelle France occidentale, dicte Canada, faits par le Sr. de Champlain Xainctongeois, capitaine pour le roy en la marine du Ponant, \& toutes les descouuertes qu'il a faites en ce paîs depuis l'an 1603 jusques en l'an 1629. Paris: C. Collet, 1623. Trans. Charles Pomeroy Otis. Voyages of Samuel de Champlain. Boston: The Prince Society, 1878-82. 3 vols.

Trans. Annie Nettleton Bourne. The Voyages and Explorations of Samuel de Champlain (1604-1616) Narrated by Himself. Ed. Edward Gaylord Bourne. New York : A.S. Barnes, 1906. 2 vols.

Trans. Michael Macklem. Voyages to New France 1599-1603. Ottawa: Oberon Press, 1971.

Trans. Michael Macklem. Voyages to New France 1615-1618. Ottawa: Oberon Press, 1970.

Euvres de Champlain. Québec : G.-E. Desbarats, 2nd ed., 1870. (The 1st ed. was destroyed by fire before printing.) Trans. H. P. Biggar et al. The Works of Samuel de Champlain. Toronto: The Champlain Society, 1922-36. 6 vols.

Charlevoix, Pierre François Xavier de. Histoire et description générale de la Nouvelle France, avec le Journal historique d'un voyage fait par ordre du roi dans l'Amérique Septentrionnale. Paris : Chez la veuve Ganeau, 1744. Trans. John Gilmary Shea. History and General Description of New France. New York : J. G. Shea, 1866-72. 6 vols.

Journal d'un voyage fait par ordre du roi dans l'Amérique Septentrionnale. Paris : Nyon, 1744. N. trans. Journal of a Voyage to North-America Undertaken by Order of the French King. Containing the Geographical Description and Natural History of that Country, Particularly Canada. London: Dodsley, 1761. 2 vols.

Hémon, Louis. "Au Pays de Québec » published with L.-J. Dalbis, Le Bouclier canadienfrançais. Paris : Éditions Spes, 1928. Trans. William Aspenwall Bradley. The Journal of Louis Hémon. New York : Macmillan, 1924.

Hennepin, Louis. Nouvelle découverte d'un très grand pays situé dans l'Amérique. Utrecht : G. Broedelet, 1697. Trans. Louis Hennepin. A New Discovery of a Vast Country in America. London : M. Bentley et al., 1698 ; rpt. Toronto : Canadiana House, 1969. 2 vols.

Nouveau voyage d'un pais plus grand que l'Europe avec les reflections des enterprises du Sieur de la Salle, sur les mines de St. Barbe,\&c. Utrecht: A Schouten, 1698. N. trans. A Continuation of the New Discovery of a Vast Country in America, Extending above Four Thousand Miles, between New France and New Mexico; Giving an Account of the Attempts of the Sieur de La Salle upon the Mines of St. Barbe etc. London : M. Bentley et al., 1698.

Lahontan, Louis Armand de Lom d'Arce. Nouveaux voyages de Mr. le Baron de Lahontan, dans l'Amérique Septentrionale, qui contiennent une relation des differents peuples qui y habitent. La Haye: l'Honoré, 1703. N. trans. New Voyages to NorthAmerica. Containing an Account of the Several Nations of that Vast Continent. London: H. Bonwicke et al., 1703.

Collection Oakes: Nouveaux documents de Lahontan sur le Canada et TerreNeuve. Éd. Gustave Lanctôt. Ottawa : Patenaude, 1940. (Bilingual text)

La Salle, Robert Cavalier, Sieur de. * Letters patent, memoirs, reporting and discoveries from the minutes. "Trans. Thomas Falconer. On the Discovery of the Mississippi, and on the South-western Oregon, and North-western Boundary of the United States. With a translation from the Original Ms. of Memoirs, etc. Relating to the Discovery of the Mississippi, by Robert Cavalier de La Salle and the Chevalier Henry de Tonty. London : S. Clarke, 1844. 
From the minute-book of the Académie Royale des Sciences for the years 1675-9 Sheet 200, verso, Sept. 3, 1678. Trans. F.C.A. Jeanneret. " An Interview on Canada with La Salle in 1678. "Canadian Historical Review. Ed. M.-L. Puech-Milhau. June. 1937. XVIII, 163-177.

Marie de l'Incarnation, Mère. Lettres de la révérende Marie de l'Incarnation (née Marie Guyard). Éd. P.-F. Richandeau. Paris : Casterman, 1876.

Écrits spirituels et historiques. Éd. Dom Albert Jamet. Paris: Desclée de Brouwer : 1929-39. Trans. Joyce Marshall. Word from New France: The Selected Letters of Marie de l'Incarnation. Toronto : Oxford Univ. Press, 1967. (A selection of 68 letters from the above texts.)

Ragueneau, Paul. Relation de ce qui est passé de plus remarquable en la mission des pères de la Compagnie de Iesus, aux Hvrons. From Relations des Jésuites dans la Nouvelle France. Québec : 1858. Trans. Joseph Fallon. Heroes of Huronia... Narrative of the Jesuit Martyrs of North America, Saints Joln de Brebeuf, Gabriel Lalement, Charles Garnier and Noel Chabanel, Slain by Iroquois in 1649. Fort Ste-Marie, Ont. : Martyr's Shrine, 1948.

The Jesuit Relations and Allied Documents : Travels and Explorations of the Jesuit Missionaries in New France, 1610-1791. Trans. and ed. Reuben Gold Thwaites. Cleveland: Burrows Bros., 1896-1901. 73 volumes. (Includes the original French, Latin and Italian texts with English translation.)

The Jesuit Relations. Selected and ed. Edna Kenton. Toronto : McClelland \& Stewart, 1901.

The Jesuit Relations and Allied Documents : A Selection. Toronto : McClelland \& Stewart, 1963.

\section{(A. 6) ESSAYS}

Angers, François-Réal. Les Révélations du crime: ou, Cambray et ses complices: chroniques canadiennes de 1834. Québec: Fréchette, 1837. N. trans. The Canadian Brigand. Montreal : Worthington, 1867.

Arseneault, Bona. Histoire et généalogie des Acadiens. Québec : Le Conseil de la vie Française en Amérique, 1965. 2 vols. Trans. Brian M. Upton and John G. McLaughlin. History of the Acadians. Quebec : Conseil de la vie française en Amérique, 1966.

Barbeau, Charles Marius. "Krieghoff découvre le Canada. "Mémoires de la Société Royale $d u$ Canada. Third series. Ottawa : Société Royale du Canada, 1934. Trans. Charles Marius Barbeau. "Krieghoff Discovers Canada. "Canadian Geographical Journal. March 1934. VIII, 101-113.

Côté, sculpteur sur bois. Ottawa: La Société Royale du Canada, 1942. Trans. Charles Marius Barbeau. Côté, the Wood Carver. Toronto: Ryerson, Canadian Art Series, 1943.

J'ai vu Québec. Québec : Librairie Garneau, 1957. Trans. Charles Marius Barbeau. 1 Have Seen Quebec. Québec : Librairie Garneau, 1957.

Bergeron, Henri Paul. Le Frère André: Yapôtre de Saint-Joseph. Montréal : Oratoire SaintJoseph, 1938. Trans. Rev. Réal Bourreau. Brother André, C.S.C.: The Wonder Man of Mount Royal. Montréal : Édition Fides, 1953.

Bergeron, Léandre. Petit manuel d'histoire du Québec. Montréal : Éditions Québécoises, 1970. Trans. Baila Markus. The History of Quebec: A Patriote's Handbook. Toronto : N.C. Press, 1971.

Bonenfant, Jean-Charles. La Naissance de la confédération. Montréal : Leméac, 1969. Trans. Grace Maurice. The French Canadians and the Birth of Confederation. Ottawa : Canadian Historical Assoc., 1966.

Bouchard, Georges. Vieilles choses, vieilles gens : silhouettes campagnardes. Montréal : Beauchemin, 1926. Trans. Alan Hunt Holley. Other Days, Other Ways: Silhouettes of the Past in French Canada. Montréal : Carrier, 1928. 
Breton, Paul-Émile. Le Grand chef des prairies, le père Albert Lacombe, O.M.I., 1827-1916. Edmonton: Ermitage, 1954. Trans. Hugh A. Dempsey. The Big Chief of the Prairies: The Life of Father Lacombe. Montréal : Palm, 1955.

Au pays des Peaux-de-Lièves : J. M. Patrick Kearney, o.m.i., héros de l'Arctique. Edmonton: Ermitage, 1962. Trans. J. S. Mullany. Irish Hermit of the Arctic: The Life of Brother J. Patrick Kearney, o.m.i. Edmonton : Ermitage, 1963.

Cadieux, Marcel. Le Diplomate canadien. Montréal : Fides, 1962. Trans. Archibald Day. The Canadian Diplomat: An Essay in Definition. Toronto : Univ. of Toronto Press, 1963.

Casgrain, Thérèse. Une Femme chez les hommes. Montréal : Éditions du Jour, 1971. Trans. Joyce Marshall. A Woman in a Man's World. Toronto: McClelland \& Stewart, 1972.

Chaput, Marcel. Pourquoi je suis séparatiste. Montréal : Éditions du Jour, 1961. Trans. Robert A. Taylor. Why I Am a Separatist. Toronto : Ryerson, 1962.

Chaput-Rolland, Solange. Mon pays, Québec ou le Canada? Montréal : Cercle du Livre de France, 1966. Trans. Solange Chaput-Rolland. My Country Canada or Quebec? Toronto : Macmillan, 1966.

Regards 1967: Québec, année zéro. Montréal: Cercle du Livre de France, 1968. Trans. Gretta Chambers. Reflections: Quebec, Year One. Montreal : Chateau Books, 1968.

Regards 1969 : la seconde conquête. Montréal : Cercle du Livre de France, 1970. Trans. Gretta Chambers. The Second Conquest : Reflections II. Montreal : Chateau Books, 1970.

Chaput-Rolland, Solange and Gwethalyn Graham (pseud. for G. Erichsen Brown). Chères Ennemies. Montréal : Éditions du Jour, 1963. Trans. Solange Chaput-Rolland and Gwethalyn Graham. Dear Enemies: A Dialogue on French and English Canada. Toronto : Macmillan, 1963.

Cloutier, Eugène. Le Canada sans passeport. Montréal : Éditions HMH, 1967. 2 vols. Trans. Joyce Marshall. No Passport: A Discovery of Cänada. Toronto: Oxford Univ. Press, 1968. (An abridged translation)

Constantin-Weyer, Maurice. Un homme se penche sur son passé. Paris : Rieder, 1928. Trans. Slater Brown. A Man Scans His Past. New York: Macaulay Co., 1929.

Costisella, Joseph. Le Scandale des écoles séparées en Ontario ; le Québec: ghetto des francais d'Amérique. Montréal : Éditions de 1'Homme, 1962. N. Trans. The Scandal of Canadian Racism; Quebec: A Ghetto for French Canadians. Ottawa : Comité canadien-français de vigilance, 1963.

Desbiens, Jean-Paul. Les Insolences du Frère Untel. Montréal : Les Éditions de l'Homme, 1960. Trans, Miriam Chapin. The Impertinences of Brother Anonymous. Montreal : Harvest House, 1962.

Sous le soleil de la pitié. Montréal : Éditions du Jour, 1965. Trans. Frédéric Côté. For Pity's Sake: The Return of Brother Anonymous. Montréal : Harvest House, 1965.

Dictionnaire biographique du Canada. Ed. Marcel Trudel and George W. Brown. Québec: Presses de l'Université Laval, 1966- . Vol. 1, 2 and 10. (Co-published with English language edition) Dictionary of Canadian Biography. Ed. George W. Brown and Marcel Trudel. Toronto : Univ. of Toronto Press, 1966- . Vol. 1, 2 and 10.

Dollier de Casson, François. Histoire de Montréal, 1640-72. Montréal : E. Senécal, 1871. Trans. Ralph Flenley. A History of Montreal, 1640-72. Toronto : Dent, 1928.

Faribault, Marcel and Robert Fowler. Dix pour un: le pari confédératif. Montréal : Les Presses de l'Université de Montréal, 1965.

Ten to One: The Confederation Wager. Toronto: McClelland \& Stewart, 1965. 
Frégault, Guy. La Guerre de la conquête. Montréal : Fides, 1955. Trans. Margaret M. Cameron. Canada: The War of the Conquest. Toronto: Oxford Univ. Press, 1969.

La Société canadienne sous le régime français. Ottawa: Société Historique du Canada, Brochures historiques, No. 3, 1956. Trans. W. M. Cocher. Canadian Society in the French Regime. Ottawa: Canadian Historical Assoc., Historical Booklets, No. 3, 1956.

Garneau, François-Xavier. Histoire du Canada, depuis sa découverte jusqu'à nos jours. Québec : N. Aubin, 1845-52. 4 vols. Trans. Andrew Bell. History of Canada, from the Time of its Discovery till the Union Year, 1840-1. Montréal : J. Lovell, 1860. 3 vols.

Grandbois, Alain. Né à Québec, Louis Jolliet. Paris : A. Messein, 1933. Trans. Evelyn M. Brown. Born in Quebec: A Tale of Louis Jolliet. Montréal : Palm, 1964.

Gros-Louis, Max One-Onti. Le « Premier » des Hurons. Montréal : Éditions du Jour, 1971. Trans. Sheila Fischman. First among the Hurons. Montréal : Harvest House, 1974.

Groulx, Lionel Adolphe, Abbé. Pourquoi nous sommes divisés. Montréal : L'Action Nationale, 1943. Trans. Gordon O. Rothney. Why We Are Divided. Montréal : L'Action Nationale, 1944.

A Selection of speeches, essays and articles. Trans. Joanne L'Heureux and Susan Mann Trofimenoff. Abbé Groulx: Variations on a Nationalist Theme. Toronto : Copp Clark, 1973.

Hébert, Jacques and Pierre Elliott Trudeau. Deux Innocents en Chine-Rouge. Montréal : Éditions de l'Homme, 1961. Trans. I. M. Owen. Two Innocents in Red China. Toronto : Oxford Univ. Press, 1968.

Hébert, Jacques. J'accuse les assassins de Coffin. Montréal : Éditions du Jour, 1963. N. trans. I Accuse the Assassins of Coffin. Montréal : Éditions du Jour, 1964.

Jette, Fernand. La Voie de la sainteté d'après Marie de l'Incarnation. Ottawa: Univ. of Ottawa Press, 1954. Trans. Mother Herman. The Spiritual Teaching of Mary of the Incarnation. Montréal : Palm, 1963.

Jouvancourt, Hughes de. Clarence Gagnon. Montréal : La Frégate, 1970. Trans. Nancy Côté. Clarence Gagnon. Montréal : La Frégate. 1970.

Cornelius Krieghoff. Montréal : La Frégate, 1971. Trans. Nancy Côté. Cornelius Krieghoff. Montréal : La Frégate, 1971.

Julien, Claude. Le Canada: dernière chance de l'Europe. Paris : B. Grasset, 1965. Trans. Penny Williams. Canada: Europe's Last Chance. Toronto : Macmillan, 1968.

Kattan, Naim. Le Réel et le théâtral. Montréal : Éditions H.M.H. 1970. Trans Allan Brown. Reality and Theatre. Toronto : House of Anansi, 1972.

Lanctôt, Gustave. Histoire du Canada. Montréal : Beauchemin, 1960. 3 vols. Trans. Margaret M. Cameron and Josephine Hambleton. A History of Canada. Toronto : Clarke, Irwin, 1963-65. 3 vols.

Le Canada et la Révolution américaine. Montréal : Beauchemin, 1965. Trans. Margaret M. Cameron. Canada and the American Revolution 1774-1783. Toronto: Clarke, Irwin, 1967.

Lapointe, Arthur J. Souvenirs et impressions de ma vie de soldat, 1916-1919. St.-Ulric, Qué.: n.p., 1919. Trans. R. C. Fetherstonhaugh. Soldier of Quebec: 1916-1919. Montréal : E. Garland, 1931.

Laurendeau, André. La Crise de la conscription, 1942. Montréal : Éditions du Jour, 1962. Selections from Le Devoir, 1947-62.

Selections from Ces choses qui nous arrivent. Montréal: HMH, 1970. Trans. Philip Stratford. André Laurendeau: Witness for Quebec. Toronto : Macmillan, 1973.

Lefebvre, Germain. Pellan. Montréal : Éditions de l'Homme, 1973. Trans. Bill Bantey. Pellan. Toronto : McClelland \& Stewart, 1973. 
Légaré, Romain, o.f.m. Un Apôtre des deux mondes : le Père Frédéric Janssoone de Ghyvelde. Montréal : Lib. Saint-François, 1953. Trans. Raphael Brown. An Apostle of Two Worlds: Father Frederic Janssoone, o.f.m., of Ghyvelde. Trois-Rivières, Qué.: Éds. du Bon Père Frédéric, 1959.

Le Moyne, Jean. Convergences, Montréal : Éditions HMH, 1961. Trans. Philip Stratford. Convergence : Essays from Quebec. Toronto : Ryerson, 1966.

Lescarbot, Marc. Histoire de la Nouvelle France, contenant les navigations, découvertes, et habitations faites par les Francois és Indes Occidentales et Nouvelle-France souz l'avou et authorité de noz rois tres-chrétiens, et les diverses fortunes d'iceux en l'execution de ces choses, depuis cens ans jusques à hui. En quoy est comprise l'histoire morale, naturelle, et geographique de la dite province: avec les tables et figures d'icelle. Par Marc Lescarbot advocat en Parlement, témoin oculaire d'une partie des choses ici recitées. Paris : Jean Milot, 1609. Trans. Pierre Erondelle. Nova Francia or the Description of that Part of New France which is one Continent with Virginia. London : A. Hebb, 1609. (A partial translation)

Trans. W. L. Grant. The History of New France by Marc Lescarbot. Toronto : The Champlain Society, 1907-14. 3 vols. (Trans. of the third ed., Paris, 1618)

Martin, Claire. Dans un gant de fer. Montréal : Cercle du Livre de France, 1965.

La Joue Droite. Montréal : Cercle du Livre de France, 1966. Trans. Philip Stratford. In an Iron Glove. Toronto : Ryerson, 1968. (Includes both the above)

Mitchell, Sour Estelle. Elle a beaucoup aimé : vie de la bienheureuse Marguerite d'Youville, fondatrice des Saurs de la Charité. Montréal : Fides, 1959. Trans. Helena Nantais. Marguerite d'Youville: Foundress of the Grey Nuns. Montréal : Palm, 1965.

Nish, Cameron, ed. Le Régime français, 1534-1760. Scarborough, Ont. : Prentice-Hall, 1966. Ed. and Trans. Cameron Nish. The French Regime. Scarborough, Ont. : PrenticeHall, 1965.

Ouellette, Fernand. Edgard Varèse. Montréal : HMH, 1966. Trans. Derek Coltman. A Biography of Edgard Varèse. New York : Orion Press, 1968.

Pelletier, Gérard. La Crise d'octobre. Montréal : Éditions du Jour, 1971. Trans. Joyce Marshall. The October Crisis. Toronto : McClelland \& Stewart, 1971.

Rioux, Marcel. La Question du Québec. Paris : Seghers, 1969. Trans. James Boake, Quebec in Question. Toronto : James Lewis \& Samuel, 1971.

Rioux, Marcel and Yves Martin. La Société canadienne-française. Montréal : Hurtubise HMH, 1971. Trans. Marcel Rioux and Yves Martin. French-Canadian Society. Toronto: McClelland \& Stewart, 1964.

Rocher, Guy. Introduction à la sociologie générale, Montréal : HMH, 1968-69. 3 vols. Trans. Peta Sheriff. A General Introduction to Sociology: $A$ Theoretical Perspective. Toronto : Macmillan, 1969.

Roquebrune, Robert de (pseud. for Robert Laroque). Testament de mon enfance. Paris : Plon, 1951. Trans. Felix Walter. Testament of My Childhood. Toronto: Univ. of Toronto Press, 1964.

Routhier, Adolphe-Basile. Québec et Lévis à l'aurore du $X X^{*}$ siècle. Montréal : Samuel de Champlain, 1900. N. trans. Quebec a Quaint Medieval French City in America, at the Dawn of the $X X^{t h}$ Century. Montréal : Montreal Printing and Publishing, 1904.

Rumilly, Robert. Histoire de Saint-Laurent. Montréal : Beauchemin, 1969. Trans. Cameron Nish. History of Saint-Laurent. Montréal : Beauchemin, 1970.

Sevigny, Pierre. Le Grand jeu de la politique. Montréal : Éditions du Jour, 1965. N. trans. This Game of Politics. Toronto : McClelland \& Stewart, 1965.

Siegfried, André. Le Canada : les deux races, problèmes politiques contemporains. Paris : Lib. Armand Colin, 1906. N. trans. The Race Question in Canada. London : E. Nash, 1907 ; rpt. Toronto : McClelland \& Stewart, 1966.

Trans. H. H. Hemming and Doris Hemming. Canada. London : 1937. 
Taché, Joseph-Charles. De la tenure seigneuriale en Canada, et projet de commutation. Québec : Lovell, 1854. N. Trans. The Seignorial Tenure in Canada, and Plan of Commutation. Quebec : Lovell, 1854.

Tanghe, Raymond. Laurier, artisan de l'unité canadienne, 1841-1919. Tours : Mame, 1960. Trans. Hugh Bingham Meyers. Laurier, Architect of Canadian Unity. Montreal : Harvest House, 1966.

Thibon, Gustave. Ce que Dieu a uni, essai sur l'amour. Lyon : H. Lardanchet, 1945. Trans. A. Gordon Smith. What God Has Joined Together : An Essay on Love. London : Hollis \& Carter, 1952 ; rpt. Love and Marriage. London : Burns \& Oates, 1962. La Crise Moderne de l'amour. Paris : Eds. Universitaires, 1953. Trans. Reginald Trevelt and S.F.L. Tye. Love at the Crossroads. Montreal : Palm, 1964.

Tougas, Gérard. Histoire de la littérature canadienne-française. 2nd ed., Paris : Presses Universitaires de France, 1964. Trans. Alta Lind Cook. History of French-Canadian Literature. Toronto : Ryerson, 1966.

Trudeau, Pierre Elliott, éd. La Grève de l'amiante: une étape de la révolution industrielle au Québec. Montréal : Cité libre, 1956. Trans. James Boake. The Asbestos Strike. Toronto: James, Lewis \& Samuel, 1974.

Le Fédéralisme et la société canadienne-francaise. Montréal : HMH, 1967. Trans. Joanne L'Heureux and Patricia Claxton. Federalism and the French Canadians. Toronto : Macmillan, 1968.

Les Cheminements de la politique. Montréal : Éditions du Jour, 1970. Trans. I. M. Owen. Approaches to Politics. Toronto: Oxford Univ. Press, 1970.

Trudel, Marcel. Histoire de la Nouvelle France. Montréal : Fides, 1963-66. Trans. Patricia Claxton. The Beginnings of New France, 1524-1663. Toronto: McClelland \& Stewart, 1973.

Vallières, Pierre. Nègres blancs d'Amérique: autobiographie précoce d'un "terroriste» québécois. Montréal: Parti Pris, 1968. Trans. Joan Pinkham. White Niggers of America: The Precocious Autobiography of a Quebec "terrorist." New York : Monthly Review Press, 1971.

\section{(A. 7) ANTHOLOGIES}

Fiction

Lucas, Alex, ed. Great Canadian Short Stories. New York: Dell Publishing, 1971. (Includes 3 stories in translation)

Mickleburgh, Brita, ed. Canadian Literature: Two Centuries in Prose. Toronto: McClelland \& Stewart, 1973. (Includes 2 selections in translation)

Stratford, Philip, ed. Stories from Quebec. Scarborough, Ont. : Van Nostrand \& Reinhold, 1974. (Includes 28 stories in translation)

Weaver, Robert and Helen James, ed. Canadian Short Stories. Toronto : Oxford Univ. Press, 1952. (Includes 2 stories in translation)

Weaver, Robert, ed. Canadian Short Stories. Toronto : Oxford Univ. Press, 1960. (Includes 3 stories in translation)

Poetry and Prose

Littlejohn, Bruce and Jon Pearce, ed. Marked by the Wild: An Anthology of Literature Shaped by the Canadian Wilderness. Toronto: McClelland and Stewart, 1973. (Includes 5 selections in translation)

Marion, Séraphin, ed. Tradition du Québec/The Quebec Tradition: An Anthology of FrenchCanadian Prose and Verse. Trans. Watson Kirkconnell. Montréal : Lumen, 1946. (Bilingual edition. Includes 34 selections in translation) 
Richler, Mordecai, ed. Canadian Writing Today. Harmondsworth, Middlesex, England : Penguin Books, 1970. (Includes 12 selections in translation)

Robins, John D., ed. A Pocketful of Canada. Toronto : Collins, 1948. (Includes 6 selections in translation)

Toye, William, ed. A Book of Canada. Toronto: Collins, 1962. (Includes 16 selections in translation)

Weaver, Robert and William Toye, ed. The Oxford Anthology of Canadian Literature. Toronto : Oxford Univ. Press, 1973. (Includes 14 selections in translation)

Poetry

Cogswell, Fred, Trans. One Hundred Poems of Modern Quebec. Fredericton : Fiddlehead, 1970. (Includes 37 poets)

A Second Hundred Poems of Modern Quebec. Fredericton, N.B. : Fiddlehead Poetry Books, 1971. (Includes 42 poets)

Colombo, John Robert, ed. How Do I Love Thee? Sixty Poets of Canada (and Quebec) Select and Introduce Their Favourite Poems from Their Own Work. Edmonton: Hurtig, 1970. (French poems appear in French and English. Includes 10 Quebec poets)

Downes, G.V., trans. When We lie Together: Poems from Quebec and Poems by G.V. Downes. Vancouver : Klanak, 1973. (Includes 7 Quebec poets)

Dudek, Louis, ed. Poetry of Our Time: An Introduction to Twentieth-century Poetry Including Modern Canadian Poetry. Toronto: Macmillan, 1965. (Includes 5 Quebec poets)

Ellipse. A quarterly review of works in translation. Sherbrooke, Québec : Faculté des Arts, Université de Sherbrooke.

Ellipse 1, Fall 1969. Includes works by Paul Chamberland, Gérald Godin, Guillevic, Paul-Marie Lapointe, Gaston Miron, Clément Moisan and Fernand Ouellette.

Ellipse 2, Winter 1970. Poems by Rolland Giguère.

Ellipse 3, Spring 1970. Poems by Michèle Lalonde.

Ellipse 4, Summer 1970. Stories by Roch Carrier.

Ellipse 5, Autumn 1970. Poems by Gaston Miron.

Ellipse 6, Winter 1971. Works by Nicole Brossard, Paul Chamberland, Gaétan Dostie, Michel Garneau, Jacques Godbout, Yves Préfontaine and Raoul Duguay.

Ellipse 7, Spring 1971. Poems by Jacques Brault.

Ellipse 8-9, 1971. Poems by Paul Chamberland.

Ellipse 10, 1972. Poems by Fernand Ouellette.

Ellipse 11, 1972. Poems by Paul-Marie Lapointe.

Ellipse 12, 1973. Works by Denis Bachand, Nicole Brossard, Jean Charlebois, Juan Garcia, Michel Leclerc, Alexis Lefrançois, Pierre Morency, Claude Péloquin and Luc Racine.

Ellipse 13, 1973. Poems by Gilbert Langevin.

Ellipse 14/15, 1974. Poems by Alain Grandbois and prose by Grandbois.

Glassco, John, ed. Poetry of French Canada in Translation. Toronto: Oxford Univ. Press, 1970. (Includes 47 poets)

Hogan, Homer, ed. Listen! Songs and Poems of Canada. Toronto : Methuen 1972. (Includes 5 Quebec poets)

Roy, George Ross, ed. and trans. Twelve Modern French Canadian Poets: Douze poètes modernes du Canada français. Toronto : Ryerson, 1958. (Bilingual edition)

Scott, F. R. The Dance Is One. Toronto: McClelland \& Stewart, 1973. (Includes 8 Quebec poets)

Weaver, Robert, ed. The First Five Years: A Selection from the Taramack Review : Toronto Oxford Univ. Press, 1962. (Includes 5 Quebec poets) 
Folksongs

Barbeau, Charles Marius. Folk Songs of French Canada. Ed. and trans. Edward Sapir. New Haven : Yale Univ. Press, 1925.

Jongleur Songs of Old Quebec. Trans. Harold Boulton. Arr. Ernest Macmillan. New-Brunswick : Rutgers Univ. Press, 1962.

Roundelays: Folk Dances and Games Collected in Canada and New England. Trans. Joy Tranter. Arr. Maurice Blackburn. Ottawa : Dept. of Northern Affairs, 1958. (Bilingual texts of French material)

Twelve Ancient French-Canadian Folk Songs. Trans. Harold Boulton. Arr. by Arthur Somervell. London : Boosey, 1927. (Bilingual edition)

Fowke, Edith Fulton, ed. and trans. Chansons de Québec. Arr. Richard Johnston. Waterloo: Waterloo Music Co., 1958. (Bilingual edition)

Folksongs of Canada. Arr. by Richard Johnston. Waterloo, Ont. : Waterloo Music Co., 1954. (Bilingual texts of French material)

More Folk Songs of Canada. Arr. by Richard Johnston. Waterloo, Ont. : Waterloo Music Co., 1967. (Bilingual texts of French-Canadian material)

Gibbon, John Murray, trans. Canadian Folk Songs. Toronto: Dent, 1949. (Bilingual texts of French material)

Lanigan, George Thomas. National Ballads of Canada: Imitated and Translated from the Originals. Montreal : Lovell, 1865.

McLennan, William, trans. Songs of Old Canada. Montreal : Dawson Bros., 1886.

Mills, Alan (pseud. for Albert Miller), ed. and trans. Chantons un peu. Toronto : BMI Canada 1961. (Includes 30 French-Canadian folk songs.)

Favourite French Folk Songs: Sixty-five Traditional Songs of France and Canada. New York : Oak Publications, 1963.

Essays

Drache, Daniel, ed. Quebec: Only the Beginning, The Manifestoes of the Common Front. Toronto: New Press, 1972. (Includes manifestoes of the C.S.N., F.T.Q. \& C.E.P.)

Kilbourn, William, ed. Canada: A Guide to the Peaceable Kingdom. Toronto : Macmillan, 1970. (Includes 12 selections in translation)

Nish, Margaret E., ed., comp. trans. Racism or Responsible Government : The French Canadian Dilemma of the 1840's. Toronto: Copp Clark, 1967. (Includes 4 selections in translation)

Scott, and Michael Oliver, eds. Quebec States her Case. Toronto : McClelland \& Stewart, 1973. (Includes 14 selections in translation)

Thomson, Dale C., ed. Quebec Society and Politics: Views from the Inside. Toronto: McClelland \& Stewart, 1973. (Includes 14 selections in translation)

\section{(A.8) BIBLIOGRAPHY}

Cotnam, Jacques. «French-Canadian Literature in Translation. \$ Contemporary Quebec: An Analytical Bibliography. Toronto: McClelland \& Stewart, 1973, pp. 72-75.

Jain, Sushil Kumar. French Canadian Literature in English Translation: A Short List Compiled from the Library Catalogues of the Regina Campus Library. Regina: Mimeographed at Regina Campus Library, 1965, pp. 10.

Leland, Marine. * French Literature of Canada ". John Hare. The Romance Literatures: The Literatures of the World in English Translation, a Bibliography. Eds. George B. Parks and Ruth Temple. New York: Ungar, 1970. Part 2. pp. 576-590.

Stratford, Philip. * French-Canadian Literature in Translation. » Meta. Montréal : Les Presses de l'Université de Montréal, 13, No. 4, December 1968. pp. 185-187. 
Sutherland, Ronald, * French-Canadian Fiction in English Translation. \& Second Image : Comparative Studies in Québec/Canadian Literature. Toronto: New Press, 1971. pp. 178-181.

"The Literature of Quebec in Translation." Read Canadian: A Book about Canadian Books. Eds. Robert Fulford, David Godfrey and Abraham Rottstein Toronto : James Lewis \& Samuel, 1972. pp. 237-245.

\section{B. TRADUCTIONS DE L'ANGLAIS EN FRANÇAIS (B. 1) ROMAN}

Barbeau, Charles Marius. The Downfall of Temlaham. Toronto: Macmillan, 1928. N. trans. Le Rêve de Kamalmouk. Montréal : Fides, 1948.

Brooke, Frances. The History of Emily Montague. London: Dodsley, 1769. 4 vols. Trans. Madame T.G.M. Voyage dans le Canada, ou Histoire de Miss Montaigu. Paris : Léopold Colin, 1809. 4 vols.

Carr, Emily. Klee Wyck. Toronto : Oxford Univ. Press, 1941. Trans. Michelle Tisseyre. Klee Wyck. Montréal : Cercle du Livre de France, 1973.

Cohen, Leonard. The Favourite Game. London: Secker and Warburg, 1963. Trans. Miche1 Doury. The Favourite Game (Le Jeu Favori). Paris : Bourgeois, 1971.

Beautiful Losers. Toronto: McClelland \& Stewart, 1966. Trans. Michel Doury. Les Perdants magnifiques. Paris : Bourgeois, 1973.

Costain, Thomas Bertram. The White and the Gold: The French Regime in Canada. Toronto: Doubleday, 1954. Trans. Charles-Marie Boissonnault. Blanc et or: le régime français au Canada. Toronto : Doubleday, 1959.

De la Roche, Mazo. Jalna. Boston : Little, Brown, 1927. Trans. Simone Sallard. Jalna. Paris : Plon, 1947.

Whiteoaks of Jalna. London : Macmillan, 1931. Trans. G. Lalande. Les Whiteoaks de Jalna. Paris : Plon, 1963.

Finch's Fortune. Toronto: Macmillan, 1931. Trans. Henriette de Sarbois. Finch Whiteoak. Paris : Plon, 1963.

The Master of Jalna. Boston : Little, Brown, 1933. Trans. G. Lalande. Le Maître de Jalna. Genève : J.-H. Jeheber, 1943.

Young Renny: Jalna-1906. Boston : Little, Brown, 1935. Trans. S. Sallard. La Jeunesse de Renny. Genève : J.-H. Jeheber, 1945.

Whiteoak Harvest. Boston : Little, Brown, 1936. Trans. G. Lalande. Moisson de Jalna. Genève : J.-H. Jeheber, 1944.

Whiteoak Heritage. Boston : Little, Brown, 1940. Trans. Gilberte Audonin-Dubreuil. L'héritage des Whiteoak. Paris : Plon, 1964.

Wakefield's Course. Boston: Little, Brown, 1941. Trans. S. Sallard. Le Destin des Whiteoak. Paris : Plon, 1962.

The Building of Jalua. Boston : Little, Brown, 1944. Trans. G. Lalande. La Naissance de Jalua. Paris : Plon, 1963.

Return to Jalua. Boston: Little, Brown, 1946. Trans. Sallard. Retour à Jalua. Paris : Plon, 1965.

Mary Wakefield. Boston : Little, Brown. 1949. Trans. G. Lalande. Mary Wakefield. Paris : Plon, 1966.

- Renny's Daughter. Boston : Little, Brown, 1951. Trans. Hélène Claireau. La Fille de Renny. Paris : Plon, 1967.

The Whiteoak Brothers: Jalna-1923. Boston : Little, Brown, 1953. Trans. Hélène Claireau. Les Frères Whiteoak. Paris : Plon, 1954.

Variable Winds at Jalna. Toronto: Macmillan, 1954. Trans. Hélène Claireau. Les Sortilèges de Jalna. Paris : Plon, 1969.

Centenary at Jalna. Boston: Little, Brown, 1958. Trans, Hélène Claireau. Le Centenaire de Jalna. Paris : Plon, 1963. 
Morning at Jalna. London : Macmillan, 1960. Trans. Sabine Berritz. Matins à Jalna. Paris : Plon, 1960.

Graham, Angus. Napoleon Tremblay. London: R. Hale, 1939. Trans. André Champroux. Napoléon Tremblay. Montréal : Beauchemin, 1945.

Guiton, Helen. A Country Lover. Toronto : Dent, 1948. Trans. Jean-L. Launay. Jean-Paul des Laurentides. Paris : Fasquelle, 1948.

Hailey, Arthur. In High Places. Toronto: Doubleday, 1962. Trans. Marie-Frence Watkins. En haut licu. Paris : Presses de la Cité, 1962.

- Hotel. Toronto: Doubleday, 1965. Trans. Marie-Anne Le Gall. Grand hotel SaintGregory. Paris : Presses de la Cité, 1966.

Airport. Toronto: Doubleday, 1968. Trans. Max Roth. Airport. Paris : Michel, 1969.

Wheels. Toronto : Doubleday, 1971. Trans. Max Roth. Detroit. Paris : Michel, 1972.

Hailey, Arthur and John Castle (pseud. for Ronald Charles Payne and John William Garrod). Flight into Danger. Toronto : Ryerson, 1958. Trans. Annie Blanchet. 714, appelle Vancouver. Paris : Julliard, 1959.

Final Diagnosis. Toronto: Doubleday, 1959. Trans. Doringe. Le dernier diagnostic. Paris : Presses de la Cité, 1960.

Houston, James. The White Dawn : An Eskimo Saga. Don Mills, Ont : Longmans, 1971. Trans. Léo Lack. L'Aube blanche. Paris : Stock, 1972.

Kirby, William. The Chien d'or. The Golden Dog: A Legend of Quebec. New York : Lovell, Adam, Wesson, 1877. Trans. Léon Pamphile Lemay, Le Chien d'or: légende canadienne. Montréal : Impr. de l'Etendard, 1884.

Laurence, Margaret. The Fire-dwellers. Toronto: McClelland \& Stewart, 1969. Trans. Rosine Fitzgerald. Ta maison est en feu. Montréal : HMH, 1971.

Leacock, Stephen. Literary Lapses. Montréal : Gazette Printing Co., 1910. Trans. Michel Chrestien. Histoires humoristiques. Paris : Laffont, 1963.

"My Victorian Girlhood." Model Memoirs. New York: Dodd Mead \& Co., 1938. Trans. Jean Gattégno. Mémoires d'une jeune fille victorienne. Paris : Lettres Modernes, 1964.

A Selection. Trans. Francine Sternberg. Leacock : Textes choisis. Paris : Julliard, 1966.

Leprohon, Rosanna Eleanor. Antoinette de Mirecourt or Secret Marrying And Secret Sorrowing. Montreal : J. Lovell, 1864. Trans. J. A. Genand. Antoinette de Mirecourt ou Mariage secret et chagrins cachés. Montréal : Beauchemin et Valois, 1865.

Lowry, Malcolm. Under the Volcano. New York : Reynal \& Hitchcock, 1947. Trans. Stephen Spriel et Clarisse Francillon. Au-dessous du volcan. Paris : Buchet-Chastel, 1963. Hear Us $O$ Lord from Heaven Thy Dwelling Place. Philadelphia : Lippincott, 1961. Trans. Clarisse Francillon et Georges Belmont. Ecoute notre voix ô Seigneur. Paris : Julliard, 1962.

Ultramarine. Philadelphia : Lippincott, 1962. Trans. Clarisse Francillon et JeanRoger Carroy. Ultramarine. Paris : Denoel, 1965.

Lunar Caustic. London: Cape, 1963. Trans. Clarisse Francillon. Lunar caustic. Paris : Julliard, 1963.

Selected Letters. Ed. Harvey Breit and Margerie Lowry. Philadelphia : Lippincott, 1965. Trans. Suzanne Kim. Choix de lettres. Paris : Denoel, 1968.

Dark As the Grave Wherein My Friend Is Laid. Toronto: General Publishing, 1968. Trans. Clarisse Francillon. Sombre comme la tombe où repose mon ami. Paris : Denoel, 1970.

October Ferry to Gabriola. New York: World Publishing, 1970. Trans. Clarisse Francillon. En route vers l'ille de Gabriola. Paris : Denoel, 1970. 
Markoosie. The Harpoon of the Hunter. Montreal : McGill-Queen's Univ. Press., 1970. Trans. Claire Martin. Le Harpon du chasseur. Montréal : Cercle du Livre de France, 1971.

MacLennan, Hugh, Barometer Rising. Toronto : Collins. 1941. Trans. Jean Simard. Le Temps tournera au beau. Montréal : HMH, 1966.

- Two Solitudes. Toronto : Collins, 1945. Trans. Louise Gareau des Bois. Deux Solitudes. Paris : Spes, 1963.

The Watch That Ends the Night. Toronto: Macmillan, 1959. Trans. Jean Simard Le Matin d'une longue nuit. Montréal : Editions HMH, 1967.

Richler, Mordecai. A Choice of Enemies. London: A. Deutsch, 1957. Trans. Daniel Apert. Le Choix des ennemis. Paris : Seuil, 1959.

- The Apprenticeship of Duddy Kravitz. London: A. Dentsch, 1959. Trans. E. Gille-Nemirovski. L'Apprentissage de Duddy Kravitz. Paris : Julliard, 1960.

- The Strcet. Toronto: McClelland \& Stewart, 1969. Trans. René Chicoine. Rue Saint-Urbain. Montréal : HMH, 1969.

Suddon, Alan. Cinderella. Trans. Claude Aubry. Ottawa : Oberon, 1969. (Edition bilingue)

Tait, George Edward. Breastplate and Buckskin: A Story of Exploration and Discovery in the Americas. Toronto : Ryerson Press, 1953. Trans. Adélard Gascon. Explorateurs et conquérants. Toronto : Ryerson, 1957.

Vineburg, Ethel S. Grandmother Came from Dworitz: A Jewish Story. Montreal: Tundra, 1969. Trans. Jacques de Roussan. L'Ä̈eule qui venait de Dworitz. Montreal: Tundra, 1969.

Whitworth, Fleur-Garneau. One Family, Two Cultures. Québec : Garneau, 1969. Trans. JeanJacques Desrochers. Une Famille, deux cultures. Québec : Garneau, 1969.

\section{(B. 2) POÉSIE}

Cohen, Leonard. Selected Poems, 1956-68. Toronto: McClelland \& Stewart, 1968. Trans. Anne Rives. Poèmes et chansons. Paris : Union Générale d'Editions, 1972.

- The Energy of Slaves. New York : Viking, 1972. Trans. Dashiell Hedayat. L'Energie des esclaves. Paris : Union Générale d'Editions, 1974.

Colombo, John Robert. The Great Wall of China: An Entertainment. Montreal : Delta, 1966. Trans. Jacques Godbout. La Grande muraille de Chine. Montréal : Editions du Jour, 1969. (Une adaptation)

Sommer, Richard, The Blue Sky Notebook. Carnet ciel blett. Montreal : Delta, 1974. Trans. Pol Chartraine. (Edition bilingue)

\section{(B. 3) THÉÂTRE}

Herbert, John. Fortune and Men's Eyes. New York: Grove Press, 1967. Trans. René Dionne. Aux yeux des hommes. Montréal : Leméac, 1971.

McDonough, John Thomas. Charbonneall and le Chef. Toronto : McClelland \& Stewart, 1968. Trans. Paul Hébert et Pierre Morency. Charbonneau et le Chef. Montréal : Leméac, 1974.

Richler, Mordecai. "The Bells of Hell Ring Ting-a-ling," (TV-Script). Trans. Gilles Rochette. Les Cloches d'enfer. Montréal : Leméac, 1974.

\section{(B. 4) LETTRES, RAPPORTS, RELATIONS DE VOYAGES}

Durham, John George Lambton, 1st Earl of. Lord Durham's Report on the Affairs of British North America. Ed. C.P. Lucas. Oxford: Clarendon Press, 1912. 3 vols. Trans, Marcel-Pierre Hamel. Le Rapport de Durham. Montréal: Editions de Québec, 1948. 
Kane, Paul. Wanderings of an Artist among the Indians of North America from Canada to Vancouver's Island and Oregon through the Hudson's Bay Company's Territory and Back Again. London : Longman, Brown,G reen, Longmans \& Roberts, 1859. Trans. Edouard Delessert. Les Indiens de la baie d'Hudson: promenades d'un artiste parmi les Indiens de l'Amérique du Nord, depuis le Canada jusqu'à l'île de Vancouver et l'Oregon, à travers le territoire de la Compagnie de la baie d'Hudson. Paris : Amyot, 1861.

Traill, Catherine Parr. The Backwoods of Canada: Letters from the Wife of an Emigrant Officer. London : C. Knight, 1836. N. Trans. Les Forêts intérieures du Canada, lettres écrites par la femme d'un officier émigrant sur la vie domestique des colons américains. Paris : L. Curmer, 1843.

\section{(B. 5) ESSAIS}

Allan, Ted, and Sydney Gordon. The Scalpel, the Sword: Story of Dr. Normand Bethune. New York: Cameron, 1952. Trans. Jean Paré. Le Docteur Bethune. Montréal : l'Etincelle, 1973.

Barbeau, Charles Marius. Quebec Where Ancient France Lingers. Toronto : Macmillan, 1936. Trans. Charles Marius Barbeau. Québec où survit l'ancienne France. Québec: Garneau, 1937.

Berton, Pierre. The Smug Minority. Toronto: McClelland \& Stewart, 1968. N. trans. Les Bien-pensants. Montréal : Editions de l'Homme, 1968.

Bowsfield, Hartwell. Louis Riel, the Rebel and the Hero. Toronto : Oxford Univ. Press, 1971. Trans. Pierre-Louis Gélinas. Louis Riel le Patriote rebelle. Montréal : Éditions du Jour, 1973.

Bracq, Jean Charlemagne. The Evolution of French Canada. New York: Macmillan, 1924. N. trans. L'Evolution du Canada français. Paris : Plon, 1927.

Cardinal, Harold. The Unjust Society : The Tragedy of Canada's Indians. Edmonton : Hurtig, 1969. Trans. Raymond Gagné et Jacques Vallée. La Tragédie des Indiens du Canada. Montréal : Editions du Jour, 1970.

Cook, Ramsay. Canada and the French-Canadian Question. Toronto : Macmillan, 1966. Trans. François Rinfret. Le Sphinx parle français: un canadien anglais s'interroge sur le problème québécois. Montréal : Eđitions HMH, 1968.

Copp, John Terry and Marcel Hamelin. Confederation: 1867. Rev. ed. Vancouver: Copp Clark, 1966. Trans. Marcel Hamelin and John Terry Copp. Confédération: 1867. Montréal : Copp Clark, 1966.

Denison, Merrill. The Barley and The Stream: the Molson Story, a Footnote to Canadian History. Toronto : McClelland \& Stewart, 1955. Trans. Alain Grandbois. Au pied du courant : l'histoire Molson. Montréal : Beauchemin, 1955.

Dictionary of Canadian Biography. Ed. George W. Brown and Marcel Trudel. Toronto : Univ. of Toronto Press, 1966-vol. 1, 2, and 10. (copublished with a French language ed. :) Dictionnaire biographique du Canada. Ed. Marcel Trudel et George W. Brown. Québec : Presses de 1'Université Laval, 1966- Vol. 1, 2, and 10.

Dobbs, Kildare. The Great Fur Opera: Annals of the Hudson's Bay Company, 1670-1970. Toronto : McClelland \& Stewart, 1970. Traduit et adapté par Jean Louis Morgan. Les Fourrures qui firent fureur: annales de la Compagnie de la Baie d'Hudson, 1670-1970. Toronto : McClelland \& Stewart, 1970.

Eccles, William John. Canadian Society during the French Regime. La Société canadienne sous le régime français. Trans. Odile Colmagne-Civitello. Montreal : Harvest House, 1968. (Edition bilingue)

Frontenac, the Courtier Governor. Toronto: McClelland \& Stewart, 1969. Trans. Françoise de Tilly. Frontenac. Montréal : HMH, 1962. 
Finkelstein, Sidney. Sense and Nonsense of McLuhan. New York : International Publishers, 1968. Trans. Philippe Burdigal. McLuhan, prophète ou imposteur. Montréal : HMH, 1970.

Fowler, Robert and Marcel Faribault Ten to One: The Confederation Wager. Toronto: McClelland \& Stewart, 1965.

Dix pour un: le pari confédératif. Montréal? Les Presses de l'Université de Montréal, 1965.

Frye, Northrop. Anatomy of Criticism: Four Essays. Princeton : Princeton Univ. Press, 1957. Trans. Guy Durand. Anatomie de la critique. Paris : Gallimard, 1969.

The Educated Imagination. Toronto : CBC, 1963. Trans. Jean Simard. Pouvoirs de l'imagination. Montreal : HMH, 1969.

The Modern Century. Toronto : Oxford Univ. Press, 1967. Trans. François Rinfret. Le Siècle de l'innovation. Montréal: HMH, 1968. Aussi La Culture face aux média. Paris : Mame, 1969.

Gordon, Walter L. A Choice for Canada: Independence or Colonial Status. Toronto : McClelland \& Stewart, 1966. Trans. Hélène J. Gagnon, Le Canada à l'heure du choix. Montréal : HMH, 1966.

Graham, Gwethalyn (pseud. for G. Erichsen Brown) and Solange Chaput-Rolland. Dear Enemies : A Dialogue on French and English Canada. Toronto: Macmillan, 1963. Trans. Gwethalyn Graham et Solange Chaput-Rolland. Chères Ennemies. Montréal : Editions du Jour, 1963.

Griggs, Mary Ann. The Folk Song in the Traditional Society of French-Canada. Sudbury : Historical Society of Ontario, Historical Document No. 53-54, 1969. (Edition bilingue)

Haggart, Ron and Aubrey Golden. Rumours of War. Toronto: New Press, 1971. Trans. Jean V. Dufresne et al. Octobre 70... Un an après. Montréal : Hurtubise HMH, 1971. (Une adaptation)

Hood, Hugh. Strength Down Centre: The Jean Béliveau Story. Scarborough, Ont. PrenticeHall, 1970. Trans. Louis Rémillard. Puissance au centre : Jean Béliveau. Scarborough, Ont. Prentice-Hall, 1970.

Hughes, Everett C. French Canada in Transition. Chicago: Univ. of Chicago Press, 1963. Trans. Jean-Charles Falardeau. Rencontre de deux mondes : la crise d'industrialisation du Canada français. Montréal : Boréal Express, 1972.

Kage, Joseph, Chapter One: Sketches of Canadian Life under the French Regime. Chapitre premier: esquisses de la vie canadienne sous le Régime français. N. trans. Montreal : Eagle, 1964. (Edition bilingue)

Klinck, Carl F., Ed. Literary History of Canada: Canadian Literature in English. Toronto : Univ. of Toronto Press, 1965. Trans. Maurice Lebel. Histoire littéraire du Canada: littérature canadienne de langue anglaise.. Laval: Les Presses de l'Université de Laval, 1970.

McDougall, John Lorne. Canadian Pacific : A Brief History. Montreal : McGill Univ. Press, N. trans. Le "Canadien Pacifique" : brève histoire de la Compagnie du chemin de fer canadien du Pacifique. Montréal : Presses de l'Université de Montréal, 1968.

McLuhan, (Herbert) Marshall. The Gutenburg Galaxy: The Making of Typographic Man. Toronto: Univ. of Toronto Press, 1962. Trans. Jean Paré. La Galaxie Gutenburg: la genèse de l'homme typographique. Montréal : HMH, 1967.

War and Peace in the Global Village: An Inventory of Some of the Current Spastic Situations that Could Be Eliminated by More Feedforward. New York : McGraw-Hill, 1968. Trans. T. Lauriol. Guerre et paix dans le village planétaire. Montréal : HMH, 1970.

Counterblast. Toronto: McClelland \& Stewart, 1969. Trans. Jean Paré. Counterblast. Montréal : HMH, 1972.

A Selection. Trans. François Chesneau. Mutations 1990. Montréal : HMH, 1969. 
McLuhan (Herbert) Marshall and Quentin Fiore. The Medium Is the Massage. Coordinated by Jerome Agel. N.Y.: Bantam, 1967. Thérèse Lauriol. Message et massage. Montréal : $\mathrm{HMH}, 1968$.

McLuhan, (Herbert) Marshall and Wilfred Watson. From Cliché to Archetype. New York : Viking Press, 1970. Trans. Derrick de Kerkhove. Du cliché à l'archétype : la foire du sens. Montréal : HMH, 1973.

Moore, William Herny. The Clash! A Study in Nationalities. Toronto: Dent, 1918. Trans. Ernest Bilodeau. Le Choc, étude de nationalités. Montréal : Beauchemin, 1920.

Osler, Edmund B. The Man Who Had to Hang : Louis Riel. Toronto : Longmans Green, 1961. Trans. Rossel Vien. Louis Riel, un homme à pendre. Montréal : Editions du Jour, 1963.

Ryerson, Stanley Bréhaut. French Canada: A Study in Canadian Democracy. Toronto: Progress, 1943. Trans. Stanley Bréhaut Ryerson. Le Canada français, sa tradition, son avenir. N. P. : Eds. La Victoire, 1945. (Une adaptation)

The Founding of Canada. Toronto : Progress Books, 1960.

Unequal Union: Confederation and the Roots of Conflict in the Canadas, 18151873. Toronto: Progress Books, 1968. Trans. André d'Allemagne. Le Capitalisme et la confédération aux sources du conflit Canada-Québec: 1760-1873. Montréal : Parti Pris, 1972. (Une adaptation)

Schull, Joseph. Laurier: the First Canadian. Toronto : Macmillan, 1965. Trans. Hélène-J. Gagnon. Laurier. Montréal : Editions HMH, 1968.

Sloan, Thomas S. Quebec: The Not-so-quiet Revolution. Toronto : Ryerson, 1965. Trans. Michel van Schendel. Une Révolution tranquille? Montréal: HMH, 1965.

Solomon, Michael. Magadan. Montréal: Chateau Books, 1971. Trans. Jacques La Salle. Magadan : l'enfer de la Sibérie. Montréal : Editions de l'Homme, 1973.

Stearn, Gerald Emanuel, ed. McLuhan Hot and Cool: A Primer for the Understanding of and a Critical Symposium with a Rebuttal by McLuhan. New York : Dial Press, 1967. Trans. G. Durand and P.-Y. Pétillon. Pour ou contre McLuhan. Paris : Eds. de Seuil, 1969.

Stern, Karl. The Pillar of Fire. New York : Harcourt, Brace, 1951. Trans. Gilberte Sollacaro. Le Buisson ardent. Paris : Seuil, 1953.

The Third Revolution: A Study of Psychiatry and Religion. New York : Harcourt, Brace, 1954. Trans. P. Bol et E. Bol. La Troisième révolution: essai sur la psychanalyse et la religion. Paris : Seuil, 1969.

The Flight from Woman. New York : Farrar, 1965. N. trans. Refus de la femme. Montréal : HMH, 1968.

Stuebing, Douglas and John Marshall and Gary Oakes. Trudeau, a Man for Tomorrow. Toronto : Clarke, Irwin, 1968. Trans. Hélène J. Gagnon. Trudeau, l'homme de demain. Montréal : HMH, 1969.

Thomson, Dale C. Louis St-Laurent, Canadian. Toronto: Macmillan, 1967. Trans. F. DufauLabeyrie. Louis St-Laurent canadien. Montréal : Cercle du Livre de France, 1968.

Wade, Mason. The French Canadians, 1760-1945. Toronto : Macmillan, 1955. Trans. Adrien Venne. Les Canadiens français de 1760 à nos jours. Montréal : Cercle du Livre de France, 1963. 2 vols.

Waite, Peter B. Pre-Confederation. Scarborough, Ont.: Prentice-Hall, 1965. Trans. André Genuist. L'Amérique britannique du nord. Scarborough, Ont. : Prentice-Hall, 1967.

Warwick, Jack. The Long Journey : Literary Themes of French Canada. Toronto: Univ. of Toronto Press, 1968. Trans. Jean Simard. L'Appel du nord dans la littérature Canadienne-française. Montréal : Editions HMH, 1972. 
Wilson, Lawrence M. Chibougamau Venture: A Narrative Adventure in a New Northern Quebec Mining Field. Montreal : Chibougameau Pub., 1952. Trans. Lawrence M. Wilson. L'Appel du Chibougamau: l'histoire d'une région minière du Québec. Montréal : n. pub., 1956.

Quebec Mining Field. Montreal : Chibougamau Pub., 1952. Trans. Lawrence M.

Yuzuk, Paul. Ukrainian Canadians: Their Place and Role in Canadian Life. Toronto: Ukranian Canadian Business \& Professional Federation, 1967. Trans. Bernard Nicoleau. Les Canadiens Ukrainiens. Winnipeg : Assoc. Ukrainienne des Lecteurs 1967.

\section{(B. 6) ANTHOLOGIES}

Fiction

Douze écrivains, douze nouvelles. Montréal : Éditions Ici Radio-Canada, March-April, 1969. (Contient 6 nouvelles)

Poetry and prose

Les Lettres Nouvelles. Numéro spécial. décembre 1966-janvier 1967. Paris : Editions Denoël. (Contient des sélections de 8 écrivains)

* Six poètes canadiens de langue anglaise ». Trans. Georges Cartier. Liberté 60. No. 8, MarchApril 1960. (Textes bilingues)

Poetry

Ellipse. Une revue trimestrielle des cuvres traduites. Sherbrooke, Qué. : Faculté des Arts, Université de Sherbrooke.

Ellipse 1, Automne 1969. Poèmes d'Earle Birney, George Bowering, Leonard Cohen, Irving Layton, Alden Nowlan and F. R. Scott.

Ellipse 2, L'hiver 1970. Poèmes de Leonard Cohen.

Ellipse 3, Printemps 1970. Poèmes de Margaret Atwood.

Ellipse 4, Eté 1970. Nouvelles de Dave Godfrey.

Ellipse 5, Automne 1970. Poèmes de Raymond Souster.

Ellipse 6, Hiver 1971. Sélections de Dave Godfrey, David Helwig, Gad Horowitz, D. G. Jones, Eli Mandel, Al Purdy, Joe Rosenblatt, Peter Stevens, Andy Wainwright.

Ellipse 7, Printemps, 1971. Poèmes de Gwendolyn MacEwen.

Ellipse 8-9, 1971. Poèmes d'Allen Ginsberg.

Ellipse 10, 1972. Poèmes de John Newlove.

Ellipse 11, 1972. Poèmes d'Irving Layton.

Ellipse 12, 1973. Douglas Barbour, Shirley Gibson, Paulette Jiles, Dennis Lee, Susan Musgrave, Andreas Shroeder, Tom Wayman, Dale Zieroth.

Ellipse 13, 1973. Poèmes de D. G. Jones.

Ellipse 14-15, 1974. Poèmes et sélections de John Glassco. 